\title{
Impact of Employer Branding on Job Satisfaction: with Special Reference to Insurance Company
}

\author{
Mendis M.V.S ${ }^{1}$ and Wanigasekera W.M.S.K ${ }^{2}$ \\ ${ }^{1}$ Department of Human Resource Management, \\ University of Kelaniya, Sri Lanka. \\ virangisonali2@gmail.com \\ ${ }^{2}$ Department of Human Resource Management, \\ University of Kelaniya, Sri Lanka. \\ sarojawanigasekara@yahoo.com
}

\begin{abstract}
Employer branding is relatively a new terminology for many companies in Sri Lanka, but it is becoming more important to today's businesses. The prime focus of this study was to investigate the relationship between employer branding and executive level employees' job satisfaction in AIA Insurance Lanka PLC. Seventy executive level employees were systematically sampled for the study. Employer branding is measured by using three dimensions such as economic value, development value and social value. Data were gathered through standardized questionnaire method and for the purpose of hypothesis testing, correlation and simple regression analysis were used by the researchers. Data were analyzed through
\end{abstract}


Statistical Package for Social Sciences 20.0 version software to find out the relationship between variables.

The results of the study suggest that there is significant positive relationship between employer branding and executive level employees' job satisfaction in AIA Insurance Lanka PLC. It was therefore suggested that organization must be a great place to work in order to enable employees to feel satisfied and remain in the organization

Keywords: Employer branding, Job satisfaction, Executive level employees

\section{Introduction}

Brands are among a firm's most valuable assets and as a result, brand management is a key activity in many firms in today's business world. Branding is frequently used to differentiate products and companies in order to build economic value to both customer and the company. According to Backhaus and Tikoo (2004) although firms commonly focus their branding efforts towards developing product and corporate brands, branding can also be used in the area of Human Resource Management (HRM) and using the application of branding principles to human resource management has been termed as employer branding. The differentiation of a firm's characteristics as an employer from those of its competitors is aimed by employer brand. Employer 
branding has become an important toolkit for human resources. It aims to communicating an attractive employer image to current and future employees by integrating marketing concepts into human resource activities (Bodderas, Cachelin \& Maas, 2010). Hoppock (1935) defined that "job satisfaction as any combination of psychological, physiological and environmental circumstances that cause a person truthfully to say I am satisfied with my job". The employees who are satisfied are the biggest assets to an organization as such employees who are dissatisfied are the biggest liabilities (Baghaei, 2011).

The objective of this study is to examine the relationship between employer branding and executive level employees' job satisfaction in AIA Insurance Lanka PLC. According to Schlager, Bodderas, Maas and Cachelin (2011) employer branding affects to job satisfaction of employees. Hence, those who are having job satisfaction tend to be more productive, creative and committed to their employer. Employer branding is relatively new concept for many companies in Sri Lanka, but it is becoming more important to today's businesses. The popularity of employer branding among human resource practitioners and the lack of academic research on the topic raises interesting questions for management scholars. This study therefore seeks to broaden the scope of research in this area in the Sri Lankan context. 


\section{Literature Review}

\section{Understanding Employer Branding}

Employer branding has emerged as a result of the application of the marketing principles to human resource management (Cable and Turban, 2001). This concept was firstly introduced in 1996 in an article presented by Ambler and Barrow. Ambler and Barrow (1996, p.187) defined the concept of employer branding as "the package of functional, economic and psychological benefits provided by employment and identified with the employing company". Here Ambler and Borrow have applied the concept of brand to HRM by viewing the employer as the brand and employees as customers. Employer branding is relatively new approach towards recruiting and retaining the best possible human talent within an employment environment that is becoming increasingly competitive. Sullivan (2004) defined employer branding as "a targeted, long-term strategy to manage the awareness and perceptions of employees, potential employees, and related stakeholders with regards to a particular firm". The result of successful employer branding gives the organization an increasing reputation and exposure, coherence among its employees and a high number of applicants as the organization will be described as a great place to work at. Minchington and Estis (2009) also define the employer brand as the image of your organization as a great place to work in the minds of current employees and key stakeholders in the external market. 


\section{Dimensions of Employer Branding}

Employer branding can be divided into three dimensions called economic value, development value and social value as recognized by Schlager et al (2011).

Economic value: Berthon, Ewing, and Hah (2005) declared that economic value comprises items such as a "good salary", "a fair number of holidays" and "reasonable retirement benefits". Firms provide benefits mostly for attracting and retaining employees and an increasing payment (or higher salary in general) is directly related to job satisfaction.

Development value: Schlager et al (2011) stated that development value category refers to variables such as "good training opportunities", an "empowering environment", and a "good mentoring culture".

Social value: According to Alniacik and Alniacik (2012) social value assesses the extent to which an individual is attracted to an employer that provides the opportunity to gain career enhancing experience, good promotion opportunities, recognition and appreciation, acceptance and belonging, good feelings and job security. 


\section{Conceptual Framework}

Conceptual Framework is prepared based on the literature of this study and following model (figure 1) has been developed for the purpose. The framework describes the relationships between economic value, development value, social value and job satisfaction. These dimensions of employer branding are labeled as independent variables. Job satisfaction is labeled as the dependent variable.

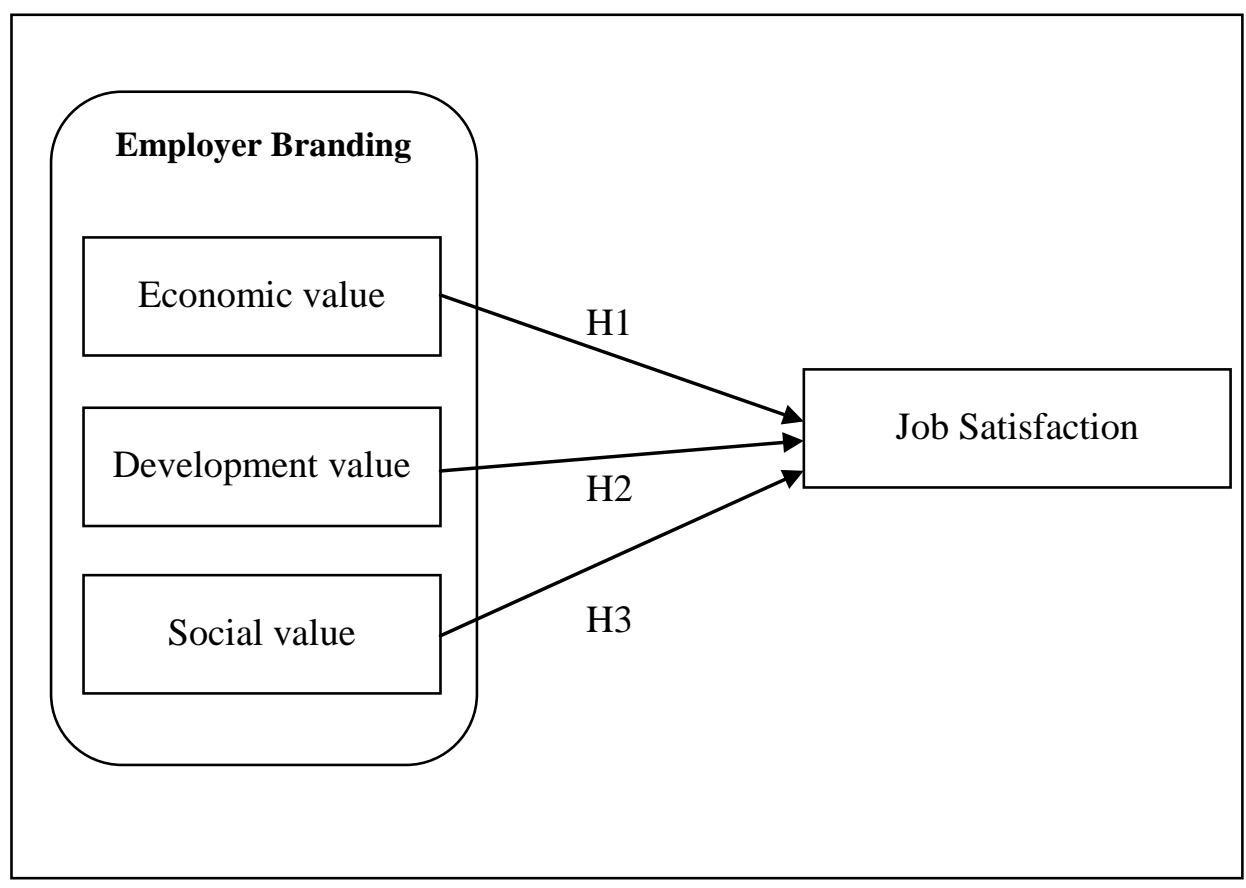

Figure 1: The Conceptual Framework 


\section{Hypotheses}

Based on the above conceptual model the following hypotheses have been formulated for this study.

$\mathrm{H} 1:$ There is a positive relationship between economic value and job satisfaction

$\mathrm{H} 2$ : There is a positive relationship between development value and job satisfaction

H3: There is a positive relationship between social value and job satisfaction

\section{Research Methodology}

The target population of this study was the executive level employees employed in AIA Insurance Lanka PLC (Head Office) which consists of 248 individuals and the sample size is calculated through PASS sample size calculator. Therefore sample of the study was 70 executive level employees in head office of AIA Insurance Lanka PLC. Data collection was done by using a self-administrated structured questionnaire. 70 questionnaires were distributed to the employees of the sample. The questionnaire consists of 40 questions and first section of it was designed to obtain demographic characteristics including age, gender, marital status, education level and the length of work experience. For the second section of it, article presented by Schlager, Bodderas, Maas and Cachelin in 2011 was used and 20 questions were asked to measure the employer branding. 
Thereafter, in order to measure job satisfaction of executive level employees, Minnesota Satisfaction Questionnaire (MSQ) developed by Weiss, Dawis, England and Lofquist in 1967 was used in the third section of the questionnaire. It contained 15 questions, which measured various aspects of the job satisfaction of the executive level employees. Some of the questions were close ended, whiles others were scored on a 5 point Likert scale of point 1 (strongly disagree) and to point 5 (strongly agree).

To test the hypotheses, Pearson's product moment correlation analysis, and simple regression analysis were used. The statistical computer package SPSS version 20.0 was utilized to analyze the data. Cronbach's alphas were 0.858 for economic value, 0.872 for development value, 0.903 for social value and 0.985 for job satisfaction suggesting that each instrument's internal consistency was satisfactory.

\section{Results}

\section{Testing of Hypotheses}

The results of Pearson's product moment correlation analysis used to test the hypothesis are presented in the Table 1. The desired level of significance is 0.01 . As this hypothesis is a directional hypothesis, one-tailed test was used. 
According to the Table 1, Pearson correlation coefficient suggest that there are positive relationships between all the independent variables. Hence there are statistical evidence to claim that positive relationships are existing between economic value, development value, social value, and job satisfaction. Therefore hypotheses of the above mentioned variables ware accepted. Further the found relationships are statistically significant, as the significant value is 0.000 which is less than the desired level of significant value of 0.01 .

Table 1: Pearson Correlation for all selected variables and job satisfaction

\begin{tabular}{|c|r|c|c|}
\hline Hypotheses & Measurement scale & Relationship & $\begin{array}{c}\text { Pearson } \\
\text { correlation } \\
\text { coefficient }\end{array}$ \\
\hline H1 & Economic value $\rightarrow$ Job satisfaction & Positive & 0.688 \\
\hline H2 & Development value $\rightarrow$ Job satisfaction & Positive & 0.751 \\
\hline H3 & Social value $\rightarrow$ Job satisfaction & Positive & 0.850 \\
\hline
\end{tabular}

** Correlation is significant at the 0.01 level (one- tailed)

The results of regressing the independent variables against the dependent variable job satisfaction are shown in the Table 2. 
Table 2: Impact of the Employer branding on Job satisfaction

\begin{tabular}{|c|c|c|c|c|c|}
\hline $\begin{array}{c}\text { Independent } \\
\text { variable }\end{array}$ & $\mathrm{R}$ & $\mathrm{R}^{2}$ & $\begin{array}{c}\text { Adjusted } \\
\mathrm{R} \text { Square }\end{array}$ & $\begin{array}{c}\text { Std. Error } \\
\text { of the } \\
\text { Estimate }\end{array}$ & $\mathrm{Sig}$ \\
\hline Economic value & .688 & .473 & .466 & .50953 & 0.000 \\
\hline $\begin{array}{c}\text { Development } \\
\text { value }\end{array}$ & .751 & .564 & .557 & .46379 & 0.000 \\
\hline Social value & .850 & .722 & .718 & .37000 & 0.000 \\
\hline
\end{tabular}

The strengths of influence that each of the independent variable had on the dependent variable. i.e. job satisfaction was determined by the use of simple regression coefficients of the independent variables. The influence of each independent variable is shown in Table 2.

$\mathrm{R}^{2}$ value of economic value indicates that $47.3 \%$ of the total variance of job satisfaction can be illustrated by economic value variable which has been selected by the researcher. The standard error of the estimate reflects as 0.509 which means the dispersion or measure of the variability in the predicted scores in regression is $50.9 \% . \mathrm{R}^{2}$ value of development value indicates that $56.4 \%$ of the total variance of job satisfaction can be illustrated by development value variable. The standard error of the estimate reflects as 0.463 which means the dispersion or measure of the variability in the predicted scores in regression is $46.3 \%$. As indicated by $\mathrm{R}^{2}$ value of social value, $72.2 \%$ of the variance of job satisfaction is explained by social value. The standard error of the estimate reflects as 0.370 which means the 
dispersion or measure of the variability in the predicted scores in regression is $37.0 \%$.

\section{Discussion}

The sample indicated that the $40 \%$ of executives are in the age range of 26-30 years and 32.9\% of the executives have 1-3years of experience. Majority (72.9\%) of executives are male. $38.6 \%$ of the executives are graduates. When considering marital status majority (75.7\%) of executives are single among executives considered for the study.

As hypothesized it was found that economic value, development value and social value have positive relationships with job satisfaction. All the three variables are significantly correlated. The findings empirically confirm the theoretical arguments explained in the literature review. Descriptive statistics reveal that job satisfaction of executive level employees is high due to employer branding. These results suggest that companies should improve their employer branding.

\section{Conclusion}

The research findings give evidence that better employer branding leads to increased employee job satisfaction. The problem of the research was to investigate the relationship between employer 
branding and the executive level employees' job satisfaction in AIA Insurance Lanka PLC. In this research the whole concept of employer branding was investigated by considering current employees. Based on the existing literature, a conceptual framework is developed so as to test the relationship between employer branding and job satisfaction. As per the research findings, it can be concluded that there is a strong positive relationship between employer branding and executive level employees' job satisfaction and this relationship is significant. This is the main objective of the study. The findings of this research study will be important both on the theoretical level and practical level. In this study researchers faced few limitations such as lack of literature in the Sri Lankan context regarding this research problem. 
Kelaniya Journal of Human Resource Management

Volume 8 Number 2 July 2013

\section{References}

Alniacik, E., \& Alniacik, U. (2012). Identifying dimensions of attractiveness in employer branding: effects of age, gender, and current employment status. Procedia-Social and Behavioral Sciences, 58, 1336-1343.

Ambler, T., \& Barrow, S. (1996). The employer brand. Journal of brand management, 4(3), 185-206.

Arachchige, B. J., \& Robertson, A. (2013). Employer Attractiveness: Comparative Perceptions of Undergraduate and Postgraduate Students. Sri Lankan Journal of Human Resource Management, 4(1), 33-48.

Aziri, B. (2011). Job satisfaction: A literature review. Management research and practice, 3(4), 77-86.

Backhaus, K., \&Tikoo, S. (2004). Conceptualizing and researching employer branding. Career development international, 9(5), 501517.

Baghaei, R. (2011). A comparative study of human resource management practices in private and public hospitals of Iran with special reference to job satisfaction of nurses

Berthon, P., Ewing, M., \& Hah, L. L. (2005). Captivating company: dimensions of attractiveness in employer branding. International journal of advertising, 24(2), 151-172.

Bodderas, M., Cachelin, J. L., \& Maas, P. (2010).Integrating marketing and human resources: The link between employee's job satisfaction, identification with the company and employer branding.In The 11th International Research Seminars in Service Management, France-May, 25-28. 
Cable, D. M., \& Turban, D. B. (2001). Establishing the dimensions, sources, and value of job seekers employer knowledge during recruitment. Research in personnel and human resources management, 20, 115-164.

Davies, G. (2008). Employer branding and its influence on managers. European Journal of Marketing, 42(5/6), 667-681.

Fernon D. (2008). Maximizing the Power of the Employer Brand. Admap, $43,49-53$

Gaddam, S. (2008). Modeling Employer Branding Communication: The Softer Aspect of HR Marketing Management. ICFAI Journal of Soft Skills, 2 (1), 45-55.

Hoppock, R. (1935). Job satisfaction. New York: Harper and Brothers.

Herzberg, F. (2003). One more time: How do you motivate employees?. Harvard business review, 81(1), 87-96.

Lakshmi, V., \& Sohail, D. (2013). Crunch Branding: The Innovative HR Tool To Lead Indian Inc In Creating Favourable Employer Branding And Employee Retention. Elixir International Journal, 54, 12507-12512.

Lloyd, S. (2002). Branding From the Inside Out. Business Review Weekly, 24(10), 64-66.

Matuska, I. F. E. (2013). Employer Branding As a Human Resources Management Strategy. Human Resources Management \& Ergonomics, 7, 35-51.

Minchington, B., \& Estis, R. (2009, May 18). 6 Steps to an employer brand strategy. Retrieved from http://www.eremedia.com/ere/6steps-to-an-employer-brand-strategy/ 
Oster, H., \& Jonze, J. (2013). Employer Branding in Human Resource Management: The Importance of Recruiting and Retaining Employees. Uppsala University. Sweden.

Schlager, T., Bodderas, M., Maas, P., \& Luc Cachelin, J. (2011). The influence of the employer brand on employee attitudes relevant for service branding: an empirical investigation. Journal of Services Marketing, 25(7), 497-508.

Saari, L. M., \& Judge, T. A. (2004). Employee attitudes and job satisfaction. Human resource management, 43(4), 395-407.

Sathya \& Indradevi, R. (2014). Branding for Talent Attraction and Retention of Employees: A Literature Review. International Journal of Scientific Research, 3, 202-204.doi: $10.15373 / 22778179$

Sekaran, U. (2006). Research methods for business: A skill building approach. New York: John Wiley \& Sons.

Sokro, E. (2012). Impact of employer branding on employee attraction and retention. European Journal of Business and Management, 4(18), 164-173.

Sullivan, J. (2004). The 8 elements of a successful employment brand. Retrieved from http://www.eremedia.com/ere/the-8-elements-ofa-successful-employment-brand/

Verma, D., \& Verma, C. (2015). A study on attractiveness dimensions of employer branding in technical educational institutions. International Journal of Marketing and Human Resource Management, 6, 36-43.

Weiss, D. J., Dawis, R. V., England, G. W., \& Lofquist, L. H. (1967). Manual for the Minnesota Satisfaction Questionnaire. Minneapolis: University of Minnesota, Industrial Relations Center 